Bangladesh J. Bot. 48(2): 231-237, 2019 (June)

\title{
GENETIC ANALYSIS OF FOUR MAIN FLAVONOIDS IN BARLEY GRAIN
}

\author{
Tao Yang, Yawen Zeng ${ }^{*}$, Juan Du, Shuming Yang and Xiaoying Pu \\ Biotechnology and Genetic Germplasm Institute, Yunnan Academy of Agricultural Sciences \\ /Agricultural Biotechnology Key Laboratory of Yunnan Province, No. 9, Xueyun Road, \\ Kunming, Yunnan, 650223, P. R. China
}

Keywords: Barley, HPLC, Flavonoids, Genetic analysis

\begin{abstract}
Genetic analysis of 4 major flavonoids in barley interspecific hybrids which were used as parents for half diallel crossingwas carried out. Compared with seven parents, the highest general combining ability of catechin content was Clipper barley, the higest general combining ability (GCA) of myricetin content were Schooner barley and Huangchangguang barley, the highest general combining ability of quercetin content were Ziguangmang barley and Kuanying barley, the highest general combining ability of kaempferol content were Ziguangmang barley and Schooner barley, the highest general combining ability of flavonoids are Schooner barley and Huangchangguang barley. The hybrid combination of a good matching were Clipper barley, Schooner barley, Ziguangmang barley and Kuanying barley, as a comprehensive general combining ability, specific combining ability, and combinations of which can be used as flavonoids in barley breeding.
\end{abstract}

\section{Introduction}

Barley is one of the medicinal and edible crops. It is rich in flavonoids which have a wide range of biological activity. It is not only the most stress tolerant and comprehensive utilized cereal, but also functional food crop in strategies to chronic diseases prevention such as reduction of obesity and Type II diabetes (Zeng et al. 2011, Zeng et al. 2012). Barley grains contain some active compouds with antibacterial, anti-inflammatory, antioxidant, scavenging free radicals, lowering blood sugar, blood fat, anti-aging, anti-cancer and other aspects (Kim et al. 2002. Yang et al. 2007). Flavonoids in barley grain are mainly catechin, myricetin, quercetin, kaempferol (Yang et al. 2009). Catechins increase the oxidation and energy consumption of fat and thus inhibit obesity (Zhang et al. 2012). Myricetin has the potential antihyperglycaemic effect (Arumugam et al. 2016). Quercetin has many biological activities and high medicinal value, including anti-inflammatory, antibacterial, anticancer, anti depression, antioxidant and so on (pandey et al. 2012). Kaempferol has the anti-inflammatory effect (Lian et al. 2016) and anticancer effect (Kashyap et al. 2017). The content of polyphenols of different genotypes of barley cultivars has wide variation in the frequency distribution curve for the approximate normal distribution (Fujita et al. 2002), The original anthocyanin gene is located at nine different mutant using half diallel cross with non-mutant procyanidins (JendeStrid 1991). Combining ability is a measure of the relative size of a parent (pure line, inbred line or variety) material's role in the performance of agronomy traits of the hybrid generation or its offspring. But combining ability of content of the catechin, myricetin, quercetin, kaempferol of barley grains has not yet been reported, The combining ability of parents in this group was determined with a method according to general combining ability and specific combining ability, on the basis of selective breeding of barley combination, it was significant for stronger heterosis of combination and excellent characters of cross combination. In this study, the excellent resourceful gene of barley has been used to create a new barley germplasm with high content of flavonoids. Genetic analysis of four major flavonoids of barley interspecific hybrids was studied by different sources of barley which

*Author for correspondence: <zengyw1967@126.com>. 
was used as parents for half diallel crossing. It could reveal quantitative genetics of the four major barley flavonoids, to study general combining ability, specific combining ability, and the additive variance, dominance variance, genetic variance, environmental variance, phenotypic variance, genetic decided degree, coefficient of variation and other genetic parameters of four major flavonoids of barley grain.

\section{Materials and Methods}

The test material of general combining ability and specific combining ability were the seven parental varieties (Table 1) and the generations of half diallel cross hybridization, preparation of hybrids (Table 2).

Table 1. The type and source of barley as the parents.

\begin{tabular}{cllc}
\hline Number & Parents & Source & Type \\
\hline 1 & Ziguangmang & China & Two edges \\
2 & Clipper & Australia & $"$ \\
3 & Huang chang guang & China & $"$ \\
4 & Schooner & Australia & $"$ \\
5 & Kuan ying & China & $"$ \\
6 & Yunpi No. 2 & China & $"$ \\
7 & Halindun & Canada & $"$ \\
\hline
\end{tabular}

The materials which were grown in the Yunnan Academy of Agricultural Sciences, their experimental was designed in RCBD with three replicates in $2 \mathrm{~m} \times 2 \mathrm{~m}$ block. Each block received the same. The seeds were sown in line with sowing depth of $2-4 \mathrm{~cm}$ and spacing was $30 \mathrm{~cm}$.

Barley seeds of parents, $F_{1} s$ generations, $F_{2} s$ were dried and crushed. Barley powder $(1 \mathrm{~g})$ was ultrasonically extracted with methanol solution about half an hour and filtered. The filtrate was evaporated, and the solids was dissolved with distilled water, extracted by ethyl acetate. The water phase was dried up, and the solids was dissolved with $10 \mathrm{ml}$ methanol, set the volume at $10 \mathrm{ml}$, filtered with a $0.45 \mu \mathrm{m}$ membrane, analized by HPLC using YMC-Pack ODS AM-303 (5 $\mu \mathrm{m}, 250$ $\mathrm{mm}-4.6 \mathrm{~mm}$ id) column. The mobile phase was A- $0.1 \%$ acetic acid aqueous solution and Bacetonitrile using gradient elution. The injection volume was $10 \mu \mathrm{l}$. flow rate was $0.8 \mathrm{ml} / \mathrm{min}$, and it was detected at $280 \mathrm{~nm}$. The content of catechin, myricetin, quercetin, kaempferol was calculated according to the peak time and the front area of the samples (Fig. 1).

The catechin, myricetin and quercetin, kaempferol, total flavonoid content of barley grain genetic were analysised by DPS, Excell software using data of of parents, $F_{1}$ and $F_{2}$ generations. with the force model of quantitative traits (NC Design ) analysis for a group of parents and $\mathrm{F}_{1}$ genetic parameters were analyzed, following Grififing's combining ability analysis (Tang and Feng 1997), general combining ability, specific combining ability, and plus variance, dominance variance, genetic variance, environmental variance, typical variance, genetically determined degree of catechin, myricetin, quercetin, kaempferol, total flavonoids content of $\mathrm{F}_{2}$ seeds of barley were analysed. 


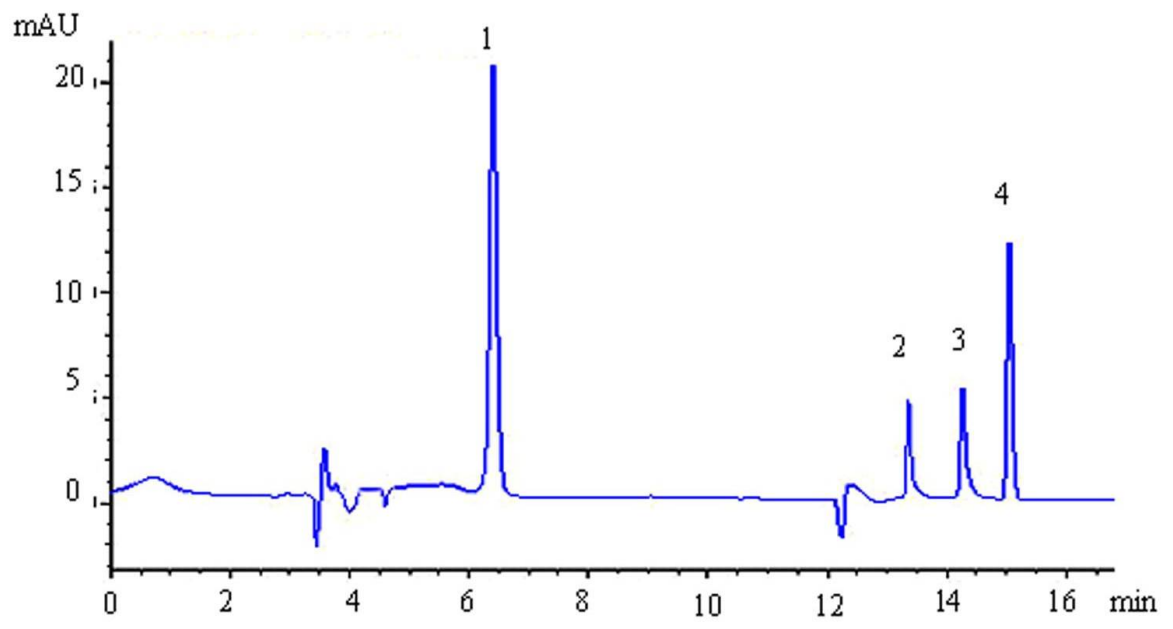

Fig. 1 Chromatograms of catechin, myricetin, quercetin, kaempferol 1 catechin 2 myricetin 3 quercetin 4 kaempferol.

Table 2. The materials for the preparation of test for half-diallel cross.

\begin{tabular}{|c|c|c|}
\hline Number & Combination & Generations \\
\hline $1 \times 2$ & Ziguangmang $\times$ Clipper & $\mathrm{F}_{1}$ \\
\hline $1 \times 3$ & Ziguangmang $\times$ Huangchangguang & $"$ \\
\hline $1 \times 4$ & Ziguangmang $\times$ Schooner & $"$ \\
\hline $1 \times 5$ & Ziguangmang $\times$ Kuanying & $"$ \\
\hline $1 \times 6$ & Ziguangmang $\times$ Yunpi No. 2 & $"$ \\
\hline $1 \times 7$ & Ziguangmang $\times$ Halindun & $"$ \\
\hline $2 \times 3$ & Clipper $\times$ Huangchangguang & $"$ \\
\hline $2 \times 4$ & Clipper $\times$ Schooner & $"$ \\
\hline $2 \times 5$ & Clipper $\times$ Kuanying & $"$ \\
\hline $2 \times 6$ & Clipper $\times$ Yunpi No. 2 & $"$ \\
\hline $2 \times 7$ & Clipper $\times$ Halindun & $"$ \\
\hline $3 \times 4$ & Huangchangguang $\times$ Schooner & $"$ \\
\hline $3 \times 5$ & Huangchangguang $\times$ Kuanying & $"$ \\
\hline $3 \times 6$ & Huangchangguang $\times$ Yunpi No2 & $"$ \\
\hline $3 \times 7$ & Huangchangguang $\times$ Halindun & $"$ \\
\hline $4 \times 5$ & Schooner $\times$ Kuanying & $"$ \\
\hline $4 \times 6$ & Schooner $\times$ Yunpi No. 2 & $"$ \\
\hline $4 \times 7$ & Schooner $\times$ Halindun & $"$ \\
\hline $5 \times 6$ & Kuanying $\times$ Yunpi No. 2 & $"$ \\
\hline $5 \times 7$ & Kuanying $\times$ Halindun & $"$ \\
\hline $6 \times 7$ & Yunpi No. $2 \times$ Halindun & $"$ \\
\hline
\end{tabular}




\section{Results and Discussion}

The difference of general combining ability of catechin, myricetin, quercetin, kaempferol, total flavonoids in 7 varieties (Table 3), was significant at 0.01 level. The highest general combining ability of catechin of barley grain was Clipper barley which was 8.68. The highest general combining ability of myricetin of barley grain was Schooner barley and huang changguang barley which were 82.57 and 76.03 , respectively, and there are no significant differences between the two varieties. The highest general combining ability of quercetin of barley grain was ziguangmang barley and kuanying barley which are 55.30 and 54.14, respectively. No significant differences were observed between the two varieties. The highest general combining ability of kaempferol of barley grain was ziguangmang barley and kuanying barley which were 2.97 and 4.58 , respectively and there were no significant differences between the two varieties. The highest general combining ability of total flavonoids of barley grain was ziguangmang barley and kuanying barley which were 66.06 and 63.95, respectively. There were also no significant differences between the two varieties. The highest general combining ability of flavonoids was total flavonoids and myricetin which shows that parents of the total flavonoids and myricetin had a greater compatibility.

Table 3. The general combining ability analysis of significant differences of flavonoids of barley grain.

\begin{tabular}{lccccc}
\hline Variety & $\begin{array}{c}\text { Catechin } \\
(\mathrm{GCA})\end{array}$ & $\begin{array}{c}\text { Myricetin } \\
(\mathrm{GCA})\end{array}$ & $\begin{array}{c}\text { Quercetin } \\
(\mathrm{GCA})\end{array}$ & $\begin{array}{c}\text { Kaempferol } \\
(\mathrm{GCA})\end{array}$ & $\begin{array}{c}\text { Flavonoids } \\
(\mathrm{GCA})\end{array}$ \\
\hline Ziguangmang & $1.28 \mathrm{bB}$ & $-69.33 \mathrm{cC}$ & $55.30 \mathrm{aA}$ & $2.97 \mathrm{aA}$ & $-9.78 \mathrm{cdBC}$ \\
Clipper & $8.68 \mathrm{aA}$ & $25.57 \mathrm{bB}$ & $-25.00 \mathrm{cdCD}$ & $1.52 \mathrm{aA}$ & $10.77 \mathrm{bB}$ \\
Huangchangguang & $0.59 \mathrm{bBC}$ & $76.03 \mathrm{aA}$ & $-2.33 \mathrm{bB}$ & $-8.23 \mathrm{bB}$ & $66.06 \mathrm{aA}$ \\
Schooner & $-1.53 \mathrm{bcBC}$ & $82.57 \mathrm{aA}$ & $-21.67 \mathrm{cC}$ & $4.58 \mathrm{aA}$ & $63.95 \mathrm{aA}$ \\
Kuanying & $-7.00 \mathrm{dD}$ & $-71.34 \mathrm{cC}$ & $54.14 \mathrm{aA}$ & $-0.64 \mathrm{aA}$ & $-24.84 \mathrm{dC}$ \\
Yunpi No2 & $-3.15 \mathrm{cCD}$ & $-68.10 \mathrm{cC}$ & $-30.13 \mathrm{dD}$ & $0.48 \mathrm{aA}$ & $-100.90 \mathrm{eD}$ \\
Halindun & $1.14 \mathrm{bB}$ & $24.59 \mathrm{bB}$ & $-30.33 \mathrm{dD}$ & $-0.67 \mathrm{aA}$ & $-5.26 \mathrm{bcBC}$ \\
\hline
\end{tabular}

The difference of specific combining ability of catechin, myricetin, quercetin, kaempferol, total flavonoids in 7 varieties was significant at 0.01 level (Table 4). The highest specific combining ability of catechin of barley grain was Ziguangmang barley $\times$ Clipper barley, Ziguangmang barley $\times$ Huangchangguang barley, Ziguangmang barley $\times$ Kuanying barley, Schooner barley $\times$ Halindun barley hybrid combination, which showed that flavonoids in these hybrid combinations had high heterosis. Among them, specific combining ability of myricetin of Ziguangmang barley $\times$ Clipper barley was up to 154.87 . Specific combining ability of catechin and quercetin of Ziguangmang barley $\times$ Huangchangguang barley combination were 23.55 and 89.01. Specific combining ability of catechin, quercetin and flavonoids of Ziguangmang barley $x$ Kuanying barley combination were $14.11,338.59$ and 373.57 , respectively.Specific combining ability of myricetin, kaempferol and flavonoids of Schooner barley $\times$ Halindun barley combination were 692.38, 32.70 and 729.57, respectively. These types of higher specific combining ability of catechin, myricetin, kaempferol, quercetin, flavonoids, indicate that these combinations are with high heterosis.

The difference of dominant variance of catechin, myricetin, quercetin, kaempferol, total flavonoids in 7 varieties (Table 5), was significant at 0.01 level, indicating that these compounds can be used in barley breeding. The difference of genetic variance and environmental variance of 
catechin, myricetin, quercetin, kaempferol, total flavonoids in 7 varieties, was significant at 0.01 level, indicating that the genetic effects of these compounds is stronger than environment effects. Genetically determined degree of myricetin and the total flavonoids were the largest, (98.93 and 98.05\%) respectively, indicating the genetic effects of these two compounds were stronger than environment effects, followed by genetically determined degree of quercetin, kaempferol, catechin were $91.96,82.01$ and $75.89 \%$, respectively.

Table 4. Specific combining ability of flavonoids of barley grain.

\begin{tabular}{|c|c|c|c|c|c|}
\hline Combinations & $\begin{array}{l}\text { Catechin } \\
\text { (SCA) }\end{array}$ & $\begin{array}{l}\text { Myricetin } \\
\text { (SCA) }\end{array}$ & $\begin{array}{l}\text { Kaempferol } \\
\text { (SCA) }\end{array}$ & $\begin{array}{l}\text { Quercetin } \\
\text { (SCA) }\end{array}$ & $\begin{array}{l}\text { Totle flavonoids } \\
\text { (SCA) }\end{array}$ \\
\hline Ziguangmang $\times$ Clipper & 5.40 & 154.87 & -5.44 & 5.57 & 160.40 \\
\hline Ziguangmang $\times$ Huangchangguang & 23.55 & 18.94 & 89.01 & -20.60 & 110.89 \\
\hline Ziguangmang $\times$ Schooner & -4.52 & -127.87 & -41.48 & 16.03 & -157.83 \\
\hline Ziguangmang $\times$ Kuanying & 14.11 & 11.45 & 338.59 & 9.42 & 373.57 \\
\hline Ziguangmang $\times$ Yunpi No. 2 & -0.88 & 8.21 & -57.77 & -29.31 & -79.76 \\
\hline Ziguangmang $\times$ Halindun & -8.27 & -84.48 & -63.92 & 12.70 & -143.97 \\
\hline Clipper $\times$ Huangchangguang & 6.23 & 344.61 & -11.62 & 2.49 & 341.72 \\
\hline Clipper $\times$ Schooner & 7.26 & -140.68 & 7.72 & -0.89 & -126.59 \\
\hline Clipper $\times$ Kuanying & -22.98 & 13.59 & -59.91 & -26.74 & -96.04 \\
\hline Clipper $\times$ Yunpi No2 & -5.84 & 26.42 & 25.70 & -1.22 & 45.05 \\
\hline Clipper $\times$ Halindun & 1.65 & -38.09 & 21.44 & -26.71 & -41.70 \\
\hline Huangchangguang $\times$ Schooner & 0.20 & 252.87 & 0.91 & -22.21 & 231.77 \\
\hline Huangchangguang $\times$ Kuanying & -14.89 & -27.31 & -16.77 & -16.99 & -75.95 \\
\hline Huangchangguang $\times$ Yunpi No. 2 & 1.43 & -41.88 & -6.49 & -18.11 & -65.04 \\
\hline Huangchangguang $\times$ Halindun & -4.34 & -170.01 & 13.52 & -11.73 & -172.57 \\
\hline Schooner $\times$ Kuanying & 6.85 & -140.45 & -1.82 & 9.68 & -125.75 \\
\hline Schooner $\times$ Yunpi No. 2 & -8.14 & 52.47 & 12.85 & -30.92 & 26.27 \\
\hline Schooner $\times$ Halindun & -8.55 & 692.38 & 13.05 & 32.70 & 729.57 \\
\hline Kuanying $\times$ Yunpi No. 2 & 2.29 & 10.22 & -38.42 & 12.40 & -13.52 \\
\hline Kuanying $\times$ Halindun & -4.52 & -82.47 & -49.02 & -3.73 & -139.74 \\
\hline Yunpi No2 $\times$ Halindun & -11.30 & -85.71 & 21.51 & 15.39 & -60.11 \\
\hline
\end{tabular}

Combining ability analysis could estimate and choose the right parents and predictive merits of hybrids (Ma 1982). The experimental results showed that general combining ability of parents was different, specific combining ability of matching crosses combination was different. It not only can reduce the breeding effort, but also shorten breeding cycle that high general combining ability of improved varieties used as backbone of parents, and that high combining ability was selected as excellent group.

On the whole, Clipper barley, Schooner barley, Ziguangmang barley, Kuanying barley had good agronomic traits, and high content of quercetin, catechin, myricetin, kaempferol, and large effect value of GCA. Therefore, they can be used as excellent parents. At present, Yunpi No. 2 
barley, Clipper barley and Schooner barley are widely spread, but Ziguangmang barley, Kuanying barley are spread little, spreading of Ziguangmang barley, Kuanying barley, for using of quercetin is needed. General combining ability of total flavonoids and myricetin were high, which shows that the total flavonoids and myricetin of parents have greater affinity. From this result, it was

Table 5. Genetic parameters of flavonoids of barley grain.

\begin{tabular}{llllll}
\hline $\begin{array}{l}\text { Genetic } \\
\text { parameters }\end{array}$ & Catechin & Myricetin & Kaempferol & Quercetin & $\begin{array}{l}\text { Total } \\
\text { flavonoids }\end{array}$ \\
\hline $\begin{array}{l}\text { Plus variance } \\
\text { Dominant variance }\end{array}$ & 15.6969 & 0.0000 & 1191.4404 & 0.0000 & 0.0000 \\
$\begin{array}{l}\text { Genetic variance } \\
\text { Environmental }\end{array}$ & $143.8941^{* *}$ & $46518.3764 * *$ & $9171.4781^{* *}$ & $458.2474 * *$ & $57251.9722 * *$ \\
variance & 32.8836 & 501.9100 & 102.0010 & 100.5549 & 1140.3057 \\
$\begin{array}{l}\text { Typical variance } \\
\begin{array}{l}\text { Genetically } \\
\text { determined degree }\end{array}\end{array}$ & $168.9292^{* *}$ & $47020.2865^{* *}$ & $8677.7589 * *$ & $558.8023 * *$ & $58392.2779 * *$ \\
\hline
\end{tabular}

observed that group of high $\times$ high or high $\times$ low could produce heterosis, which is similar to the results reported by Liang (2005). They found that isoflavones of soybean are complicated by the high breeding of high isoflavone material which should be chosen as one of the parents, matching the best combination parental types with high $\times$ high or high $\times$ low type of setup. $\mathrm{F}_{2} \mathrm{~S}$ performant genetic diversity of flavonoids, one can select the target from the $F_{2} s$ to provide raw material for breeding.

\section{Acknowledgements}

This work was supported by Yunnan Applied Basic Research Project (2014FB159); Yunnan technology Innovation Personnel Training Project (2015HB103); China Agriculture Research System (CARS-05); 2018 Yunnan Agricultural Foundation Projects.

\section{References}

Arumugam A, Palanisamy UD, Chua KH and Kuppusamy UR 2016. Potential antihyperglycaemic effect of myricetin derivatives from Syzygium malaccense. Journal of Functional Foods 22: 325-336.

Fujita M, Takeda K, Kohyama N, Doi Y and Matsunaka H 2002. Genotypic variation in polyphenol content of barley grain. Euphytica 124: 55-58.

Jende Strid B 1991. Gene-enzyme relations in the pathway of flavoniod biosythesis in barley. Theor. Appl. Gen. 81: 668-674.

Kashyap D, Sharma A, Tuli HS, Sak K, Punia S and Mukherjee TK. 2017. Kaempferol-A dietary anticancer molecule with multiple mechanisms of action: Recent trends and advancements. Journal of Functional Foods 30: 203-219

Kim MC, Panstruga R, Elliott C, Müller J, Devoto A, Yoon HW, Park HC, Cho MJ and Schulze-Lefert P 2002. Calmodulin interacts with MLO protein to regulate defense against mildew in barley. Nature 416: 447-451.

Lian JJ, Cheng BF, Gao YX, Xue H, Wang L, Wang M, Yang HJ and Feng ZW 2016. Protective effect of kaempferol, a flavonoid widely present in varieties of edible plants, on IL-1 $\beta$-induced inflammatory response via inhibiting MAPK, Akt, and NF- $\mathrm{BB}$ signalling in SW982 cells. Journal of Functional Foods 27: $214-222$ 
Liang HZ, Li WD, Fang XJ, Cao YN and Wang H 2005. Combining ability and heterosis of isoflavones and their component content of soy. Sci. Agr. Sin. 38: 2147-2152

Ma YH 1982. The basis of quantitative genetics of plant breeding. Nanjing: Jiangsu science and technology press. pp. 1-470.

Pandey AK, Patnaik R, Muresanu DF, Sharma A and Sharma HS 2012. Quercetin in hypoxia-induced oxidative stress: Novel target for neuroprotection. International Review of Neurobiology 102:107-146

Tang QY and Feng MG 1997. Practical Statistics and Computer Processing Platform. Beijing: China Agicultural Press: 34-98.

Yang T, Duan CL, Yang SC, Wen GS, Zeng YW and Xiao FH 2009. HPLC determination of catechin, myricetin, quercetin, and kaempferol in barley grain. J. Trit. Crops 29: 618-622.

Yang T, Zeng YW, Xiao FH, Pu XY, Du J and Yang SM 2007. Research progress on barley and its active substance. J. Trit. Crops 27: 1154-1158

Zeng YW, Du J, Pu XY, Yang SM, Yang SM, Yang T and Jia P 2011. Strategies of functional food for hypertension prevention in China. J. Med. Plants Res. 5: 5671-5676.

Zeng YW, Zhao CY, Pu XY, Yang T, Du J and Yang SM 2012. Identification of quantitative trait locus (QTLs) for $\gamma$-aminobutyric acid content in grain of barley. Afr. J. Biotech. 11: 1754-1760.

Zhang Y, Yu YJ, Li X, Meguro S, Hayashi S, Katashima M, Yasumasu T, Wang JZ and Li KJ 2012. Effects of catechin-enriched green tea beverage on visceral fat loss in adults with a high proportion of visceral fat: a double-blind, placebo-controlled, randomized trial. Journal of Functional Foods. 4: 315-322

(Manuscript received on 18 August, 2017; revised on 14 July, 2018) 